\title{
Turning Points and Shifting Understandings of European Security: The European Neighbourhood Policy's Development
}

\section{Maria Raquel Freire and Licinia Simão}

The European Union (EU) plays a fundamental role in Europe's security. The EU's capabilities are undergoing significant changes, which are increasingly reflected in the conceptual design of its Neighbourhood Policy (ENP). These changes result both from the external context within which EU policies are implemented and from the institutional and political context in which they are designed. Regarding the former, we identify several turning points which have affected European security since the inception of the ENP, in 2003. These include developments in EU-US relations, the North Atlantic Treaty Organisation (NATO) and EU enlargements in a post-9/11 context, the important role of Russia and its relations with former-Soviet countries, as well as the Arab Spring events and the political instability in the Southern neighbourhood of the EU. Regarding EU institutional and political context, we focus on the impacts of the $2004 / 2007$ EU enlargements, particularly in terms of the regional agenda that was uploaded onto the EU's regional security con-

M. R. Freire $(\bowtie) \bullet$ L. Simão

Faculty of Economics and Centre for Social Studies, University of Coimbra, Coimbra, Portugal

e-mail: rfreire@fe.uc.pt; lsimao@fe.uc.pt

(C) The Author(s) 2020

R. Fawn (ed.), Managing Security Threats along the EU's Eastern

Flanks, New Security Challenges, https://doi.org/10.1007/978-3-030-26937-1_2 
cerns in its articulation with the adoption of the European Security Strategy (ESS) of 2003. Following enlargement, the adoption of the Lisbon Treaty in $2009^{1}$ further imposed new adjustments and perspectives on the EU's external presence, namely the consolidation of its Common Security and Defence Policy (CSDP), as well as on its ability to be a coherent actor internationally, to which the ENP sought to contribute. ${ }^{2}$ Finally, the adoption of the 2016 Global Strategy for the European Union's Foreign and Security Policy (EU Global Strategy) reflects the ongoing trends and future ambitions of the EU's security role.

These structuring elements in the EU's regional security actorness emerge from the mapping of EU priorities and areas of action, as well as from the official discourse and policy development, which have increasingly been addressing security issues. Building on this exercise, the chapter aims at contributing to the conceptualisation of the EU's security role and of the ENP as a regional security policy, thus contributing to the wider debate on the EU's actorness. We put forward an analytical grid combining different understandings of the EU's reasoning and practice of regional security. We combine structural elements of security dealing with the promotion of liberal economic and political reforms and hard security provision, which addresses the EU's ability to intervene in the peaceful settlement of conflicts and crisis management in the neighbourhood. We reject a view of these components and dimensions of security as dichotomous and see them rather as co-existing conceptual and operational tools that reflect the historical evolution of the EU's capabilities to act beyond its borders to promote specific views of security. Whereas at an early stage these were driven by the European Commission through its programmes of reform, namely in accession processes, and later on also through specific policies, such as the Neighbourhood Policy, the adoption of new measures aimed at providing the EU with military and civilian tools for crisis management and conflict settlement allowed the Union to become a security actor on hard security issues. These complementary paths have allowed for the development of tools and policies that include both civilian and military means, pushing the EU to act both structurally and in a more muscled

\footnotetext{
${ }^{1}$ Lisbon Treaty, 'Treaty of Lisbon, Amending the Treaty on the European Union and the Treaty establishing the European community', Official Journal of the European Union, 2007/C 306/01, 17 December 2007.

${ }^{2}$ The ENP is a far-reaching policy in terms of sectorial areas, with a strong economic and trade dimension complemented by policies directed at political reforms, security issues, educational and cultural spheres, among other.
} 
way. In a sense, by combining the two dimensions, the EU is developing a comprehensive approach to security, ${ }^{3}$ close to the concept of peacebuilding proposed by the United Nations. ${ }^{4}$ We also deal with the concepts of 'normative and geopolitical actorness'-terms that are not new to the EU's conceptualisation but that allow a reading of its actuation through complementary perspectives as further analysed in the chapter. Again these two concepts-normative and geopolitical-are not understood as a dichotomy but rather as additional conceptual tools to grasp both the rationale driving EU security policies in the neighbourhood and the definition of the EU's security actorness. Table 2.1 synthetises the grid of analysis.

This grid allows an integrated look at the components and dimensions of security in these different perspectives, bringing together soft and hard approaches to security as well as normative and geopolitical considerations. The vision of security that results from this integrated approach and that the chapter explores is grounded in a non-traditional reading of security that encompasses both material and ideational factors in its analysis.

The chapter starts with the development of the analytical grid combining structural security, hard security and geopolitical and normative actorness. It then moves on to the analysis of the identified turning points, seeking to address the shifting understandings driving these changes and how these contribute to the definition of the EU as a security actor. We argue that there have been shifts in the EU's approach towards regional security in the framework of the ENP, which are particularly salient in the identified turning points. A clear trend towards a more systematic combination of structural and hard security elements is visible, reflecting both new EU institutional capabilities and a propitious international environment, demanding integrated and comprehensive approaches to security. To our understanding, the EU's security actorness in the neighbourhood has benefited from this developing comprehensive approach, ingraining a

Table 2.1 Components and dimensions of EU security actorness

\begin{tabular}{lll}
\hline Security types & Structural & Hard \\
\hline Security actorness & Normative & Geopolitical \\
\hline
\end{tabular}

\footnotetext{
${ }^{3}$ European Commission and EEAS, 'The EU's Comprehensive Approach to External Conflict and Crisis' (Brussels: EU, 2013).

${ }^{4}$ Eli Stamnes, 'The European Union and Peacebuilding', Norwegian Institute of International Affairs, Policy Brief Series, 3 March 2016.
} 
mix of normative and geopolitical aspects reflected in the EU's selfperception and its international image.

\section{Defining the EU's Security Actorness}

According to Bretherton and Vogler, ${ }^{5}$ the EU's security actorness might be defined by three main elements: the EU's ability to be present and 'exert influence externally, to shape perceptions, expectations and behaviour of others'; the EU's ability to take the opportunity to act in face of 'ideas and events that constrain or enable actorness'; and the EU's ability to respond through 'the availability of policy instruments and understandings (...) in response to opportunity and/or to capitalize on presence'. Thus, according to the authors, presence, opportunity and capability define the EU's security actorness. ${ }^{6}$ This understanding mirrors the EU's evolution as a security actor and how the EU's regional security role has been projected in its Neighbourhood Policy.

Since the beginning, European integration had a clear security dimension in seeking to avoid a relapse into violent conflict in Europe after the Second World War. Economic integration was the driver to foster cooperative relations and became the basis for the security community that developed with time. ${ }^{7}$ The EU's security actorness results from a combination of objectives and means defined through time and that clearly responds to changes in context, both externally and within the process of

${ }^{5}$ Charlotte Bretherton and John Vogler, The European Union as a Global Actor, 2nd ed. London: Routledge, 2006, p. 24.

${ }^{6}$ Several authors have addressed the EU's actorness in the field of security. Attention has been paid to the evolving role European integration has played in European security in the post-Cold War context. See Steve Marsh and Wyn Rees, The European Union in the Security of Europe: From Cold War to Terror War. Oxon: Routledge, 2012. Particular attention has been paid to the security goals EU leaders attributed to enlargement, as well as to the Union's increasingly securitized border management and engagement in counterterrorism. See Atsuko Higashino, 'For the Sake of "Peace and Security"? The Role of Security in the European Union Enlargement Eastwards', Cooperation and Conflict (Vol. 39, no. 4, 2004), pp. 347-368. Christian Kaunert, 'Europol and EU Counterterrorism: International Security Actorness in the External Dimension', Studies in Conflict \& Terrorism (Vol. 33, no. 7, 2010), pp. 652-671.

${ }^{7}$ Karl Deutsch et al., Political Community and the North Atlantic Area. Princeton, NJ: Princeton University Press, 1957. Ole Waever, 'Insecurity, security, and asecurity in the West European non-war community', in Emmanuel Adler and Michael Barnett (eds) Security Communities. Cambridge: Cambridge University Press, 1998, pp. 69-118. 
EU development. Structural security, meaning the promotion of liberal values and political democratic reforms, has been part of the EU project since early on. Successive enlargements of the European Communities clearly illustrate this, having been formalised in the Copenhagen accession criteria. $^{8}$ The 2003 European Security Strategy, ${ }^{9}$ as the first official document seeking to define a Security Strategy for the EU, recognised this structural dimension of security as most relevant, underlining that 'the progressive spread of the rule of law and democracy has seen authoritarian regimes change into secure, stable and dynamic democracies. Successive enlargements are making a reality of the vision of a united and peaceful continent'. Moreover, regarding EU external relations, this structural security dimension has always been present, with the neighbourhood probably becoming its best example, but similar emphasis on reforms has been integrated into the Union's conditionality on development, as well as stabilisation and conflict settlement policies.

Additionally, the understandings about threats and security changed as a result of a more complex international system. The loosening of borders with transnational flows of illegal trafficking in arms, drugs and people as well as of financial transactions, new subnational actors such as terrorist organisations or civil society associations, prompted rethinking traditional approaches to security and identifying new threats. As J. Peter Burgess asserts:

The threats facing Europe, no longer exclusively 'hard', but rather often 'soft', no longer respect the geopolitical borders of the nation-state and the EU. More importantly still, they traverse and resist the institutional 'borders' and arrangements traditionally designed to manage them (social agencies, informational authorities, police, etc.). The most significant effect of this shift is that the lives of citizens are no longer regulated at the physical borders. (...) At the same time, a growing number of European and international organizations have taken on increasingly dominant roles entirely detached from nation-state sovereignty, further contributing to the

\footnotetext{
${ }^{8}$ Copenhagen European Council, Conclusions of the Presidency, 21-22 June 1993, SN 180/1/93 REV 1.

${ }^{9}$ European Security Strategy, 'A Secure Europe in a Better World', Brussels, 12 December 2003 , p. 1.
} 
interrelatedness of non-national institutions and regions, and further weakening both the role and capacity of traditional sovereignty arrangements. ${ }^{10}$

These developments meant that in the process of consolidation of the Communities the establishment of complementary instruments to the structural security approach was required. This paved the way for the adoption of military and civilian tools directed at addressing instability, particularly at EU borders and beyond these. New civilian and military means, including the deployment of missions, were slowly developed conferring on the EU capacity to act in crisis management. ${ }^{11}$ The security actor gained visibility and capability to act in different contexts, with the Common Security and Defence Policy (CSDP) signalling this move. Through the internal institutional rearrangement of the EU's structures, the Lisbon Treaty (2009) formalised this comprehensive approach to security. The position of the High Representative of the EU for Foreign Affairs and Security Policy (HR), being both a vice president of the Commission and permanent chair of the Foreign Affairs Council (as well as heading the European Defence Agency), illustrates the internal adjustments made by the Lisbon Treaty. The position reinforces coherence of EU structural and hard power mechanisms, as well as the pull of Community and member states capabilities for the development of a comprehensive approach to security. Due to its geographical proximity, the ENP has been one of the first EU policies to develop and deploy a comprehensive understanding of security, combining all relevant EU instruments and policies towards the goal of comprehensive security, as the following sections elaborate.

\section{Establishing the ENP in a Post-9/11 Context}

The EU's enlargements of 2004 and 2007, in particular, profoundly changed the external borders of the Union by bringing the EU to the borders of Belarus, Moldova, Ukraine and Russia, as well as enlarging the EU's presence in the Mediterranean, with the inclusion of Cyprus and Malta. This also meant that the security context where the EU is acting

${ }^{10} \mathrm{~J}$. Peter Burgess, 'There is No European Security, Only European Securities', Cooperation and Conflict (Vol. 44, no. 3, 2009), p. 315.

${ }^{11}$ Michael Merlingen and Rasa Ostrauskaite (eds) European Security and Defence Policy: An Implementation Perspective. Oxon: Routledge, 2008. 
changed. By establishing the European Neighbourhood Policy (ENP) $)^{12}$ in 2003 , the EU aimed to deepen relations with the new neighbours through a broad cooperative approach sustained on liberal democratic principles that form the core of the EU's structural approach to security. ${ }^{13}$ Similar to the enlargement process, the ENP represented the new framework for managing future EU relations with its neighbourhood. The ENP founding documents referred to 'the prospect of a stake in the EU's internal market and further integration and liberalization to promote the free movement of persons, goods, services and capitals'. ${ }^{14}$ In order to achieve these benefits, neighbouring countries were required to engage in wideranging reforms, established in bilateral ENP Action Plans. ${ }^{15}$ From the EU's perspective, this would contribute significantly to the promotion of an enlarged area of security and prosperity and to stability at the EU border. ${ }^{16}$ The ESS, adopted also in 2003, was designed in line with these objectives, highlighting as one of its main priorities the extension of the zone of peace and stability to the whole of Europe. Other priorities included the promotion of effective multilateralism through the strengthening of the international order and on the basis of multilateral institutions and international law, as well as responses to new threats, such as organised crime, failed states and terrorism. The dynamic character of these threats meant that the EU needed to deal with them in a preventive mode, through political and economic means, ${ }^{17}$ as well as developing new

${ }^{12}$ The countries part of the ENP are Armenia, Azerbaijan, Belarus, Georgia, Moldova and Ukraine from the post-Soviet space, and nine Mediterranean countries plus one (the Palestinian Authority), which include Algiers, Egypt, Israel, Jordan, Lebanon, Libya, Morocco, Syria and Tunisia.

${ }^{13}$ See Communication from the Commission, 'Wider Europe Neighbourhood. A New Framework for Relations with our Eastern and Southern Neighbours', COM (2003) 104, Brussels, March 2003.

${ }^{14}$ Communication from the Commission, 'Paving the Way for a New Neighbourhood Instrument', COM (2003) 393, Brussels, July 2003.

${ }^{15}$ The Action Plans are non-legally binding documents, country-specific, and follow a number of agreed benchmarks. These were negotiated on the bases of already existing agreements between the Union and these countries, specifically Partnership and Cooperation Agreements or Association Agreements.

${ }^{16}$ Communication from the Commission, 'Wider Europe Neighbourhood. A New Framework for Relations with our Eastern and Southern Neighbours', COM (2003) 104, Brussels, March 2003, p. 4.

${ }^{17}$ Maria Raquel Freire, 'Challenges and opportunities at the EU's vicinity: assessing policies and practices', in Teresa Cierco Gomes (ed.), The European Union and Its Immediate Neighbourhood (Aldershot: Ashgate, 2013). 
capabilities, reflecting both the EU experience focusing on structural security and the ambition of developing new instruments and capabilities to address hard security challenges.

The Union's enlargement clearly brought new challenges closer to the EU's borders, which has been translated in this rationale for action, implying the stabilisation of the EU's neighbourhood, through a mix of reforms and conflict management, acknowledging the strong linkages between the two areas. By bringing its borders closer to the South Caucasus and Moldova, for example, the EU also became closer to the protracted conflicts in this space, namely Transnistria, Abkhazia, South Ossetia and Nagorno-Karabakh. Moreover, the 2003 ESS must be read as a document responding also to the challenges brought about by the September 11 terrorist attacks in the United States, and thus reflecting concerns with 'rogue states', the proliferation of weapons of mass destruction and terrorism, and thus requiring an a EU strategic culture that responds to these challenges.

The neighbourhood is identified as a key space where reform-oriented policies are essential to counter the new threats. Thus, the ESS clearly frames EU interventionism as mixing policy instruments, of both a civilian and a military nature, and calls for the development of strategic partnerships with countries that might assist the EU in the pursuit of its security goals, including Russia. The establishment of the ENP in the context of the Union's enlargement and in the broader post- $9 / 11$ context presents the EU as a reactive security actor in search of ways to address these multiple challenges. But it also seeks to expand the geopolitical reach of its governance model, presented as the best option for these countries to develop their societies out of poverty and conflict.

Thus, the ENP shows how the normative and geopolitical actor has evolved with time. The normative underpinnings based on the liberal model, projected through the enlargement and neighbourhood policies, have been complemented by the geopolitical dimension that the inclusion of new members and the changing of the EU external borders implied. This has also translated into a new combination of norm-based approaches to regional security, including diplomacy, preventive approaches and cooperative frameworks (which are the bases of the security community model), with more muscular, interest-driven and conditionality-based approaches (reflecting power differentials in EU relations with its neighbours).

Relations with Russia were ultimately a key factor in the definition of European security in both normative and geopolitical terms. The distinctive character of Russia's political model and its limited engagement in the post-Soviet space during the 1990s created the perception in EU capitals 
and institutions that enlargement would provide a window of opportunity for the Union to take on a more significant role as a regional stabiliser. However, as the war in Georgia, in 2008, and in Ukraine, in 2014, illustrate, the 'shared neighbourhood' implied different and, at times, competitive approaches coming from the EU and Russia. ${ }^{18}$ The EU's security actorness must therefore be understood as comprehensive in its reach and dimensions, mobilising both structural and hard security tools and seeking to advance both normative and geopolitical goals.

\section{Reacting to the Georgian War in a Post-Lisbon CONTEXT}

EU policy towards the post-Soviet countries for most of the 1990s and early 2000s lacked strategic guidance and adequate means. The ENP gradually created the conditions for the EU to assert itself as a relevant regional partner for these countries, using the weight and attractiveness of its internal market, its assistance policies and political capital, especially in their (often difficult) relations with the Russian Federation. From the view point of Moscow, the establishment of a EU neighbourhood policy focusing on the countries of the former Soviet Union, which the Kremlin perceives as an area of privileged interests, was a geopolitical step by the Union, requiring careful monitoring. ${ }^{19}$ The geopolitical potential of the ENP became immediately visible as the colour revolutions in Georgia (2003) and Ukraine (2004) unfolded, bringing to power leaders with clear pro-western foreign and domestic policy agendas and, in some cases, a clear anti-Russian stance. EU support to what Moscow portrayed as externally driven regime changes was a game changer in the shared neighbourhood between the EU and Russia. Moreover, the lack of a clear EU policy towards the protracted conflicts in the post-Soviet space, namely in Georgia, has also been criticised by the separatist authorities, namely in Abkhazia, as emboldening the Georgian government's policies of forceful reintegration of the two separatist territories into Georgia. ${ }^{20}$

\footnotetext{
${ }^{18}$ Derek Averre, 'Competing rationalities: Russia, the EU and the "Shared Neighbourhood"', Europe-Asia Studies 61: 10 (2009), pp. 1689-1713.

${ }^{19}$ Licínia Simão and Vanda Amaro Dias, 'The securitization of the EU's Eastern neighbourhood: What role for Russia?', in Remi Piet and Licínia Simão (eds), Security in Shared Neighbourhoods - Foreign Policy of Russia Turkey, and the EU (London: Palgrave Macmillan, 2016).

${ }^{20}$ Interviews conducted by the authors with the de facto leaders of Abkhazia, Sukhum/i, November 2013.
} 
This gradual consolidation of a political and economic EU presence in the post-Soviet space contributed to the broad deterioration of relations between Russia and western institutions. This included bilateral Russia-US relations, namely during the second Bush Administration. In the two presidencies of George W. Bush, US foreign policy towards Eurasia was extremely active, including US military cooperation, political support for pro-western leaders, strong support to democracy promotion, and for NATO enlargement to Ukraine and Georgia. Broader tensions linked to the Kosovo unilateral declaration of independence, US plans to develop and deploy a nuclear defence shield in Europe, as well the disengagement from disarmament treaties, all contributed to a low in Russia's relations with the US and its European partners.

The US recognition of Kosovo's independence was a game changer in Russia's foreign policy towards the separatist regions in Georgia. In 2008, Russia intervened militarily in Georgia, as a response to the Georgian government's military actions in South Ossetia, resulting in the Russian occupation of Abkhazia and South Ossetia, and reinforcing the separation of these territories from Georgia. Despite the presence of Russian peacekeepers in the area, the Russian intervention gained a new military and political dimension through the use of force and the recognition of the independence of these two republics. Russia's actions placed a great deal of pressure on the EU's structural approaches to security, developing under the ENP, as these proved inadequate to address both Georgia's conflict settlement needs and Russia's regional geopolitical ambitions. ${ }^{21}$ Although the EU had been developing significant defence capabilities since 2003, and had deployed several CSDP missions, including in Georgia, the political leverage and the diplomatic means to exert influence over this region proved inadequate.

The response of the EU to these events came in the form of the Eastern Partnership (EaP). ${ }^{22}$ The EaP was an attempt to revamp the political presence of the EU in its eastern neighbourhood, deepening the economic integration and political association of these countries to the EU. ${ }^{23}$ Table 2.2 synthesises the key negotiation points in EU-EaP countries' relations. It was the EU's understanding that, in the absence of NATO

\footnotetext{
${ }^{21}$ Licínia Simão, The EU's Neighbourhood Policy towards the South Caucasus: Expanding the European Security Community (London: Palgrave Macmillan, 2018).

${ }^{22}$ The EaP covers the six former Soviet countries, Armenia, Azerbaijan, Belarus, Georgia, Moldova and Ukraine.

${ }^{23}$ Council of the European Union, Joint Declaration of the Prague Eastern Partnership Summit. 8435/09 (Presse 78), Brussels/Prague, 7 May 2009.
} 
Table 2.2 Mapping major steps in EU relations with EaP countries

\begin{tabular}{|c|c|c|}
\hline Country & Major agreements & Major topics \\
\hline \multirow[t]{6}{*}{ Armenia } & 1999_Partnership and Cooperation Agreement & Democratic reforms \\
\hline & 2003-EU Special Representative for the South & Economic \\
\hline & Caucasus & integration \\
\hline & 2006-ENP Action Plan & Visa issues \\
\hline & 2014-Visa facilitation and readmission agreements & Nagorno-Karabakh \\
\hline & $\begin{array}{l}\text { 2017-EU-Armenia comprehensive and enhanced } \\
\text { partnership agreement }\end{array}$ & \\
\hline \multirow[t]{6}{*}{ Azerbaijan } & 1999_Partnership and Cooperation Agreement & Energy development \\
\hline & 2003-EU Special Representative for the South & Democracy and \\
\hline & Caucasus & Human Rights \\
\hline & 2006-ENP Action Plan & Nagorno-Karabakh \\
\hline & 2006-Strategic Energy Partnership & \\
\hline & $\begin{array}{l}\text { 2017-Initiated negotiations towards a new political } \\
\text { agreement }\end{array}$ & \\
\hline \multirow[t]{5}{*}{ Belarus } & 1999_Partnership and Cooperation Agreement & Democracy and \\
\hline & Dialogue on technical matters, including visa & Human Rights \\
\hline & facilitation and readmission agreements & Energy transit to \\
\hline & Cooperation under the EaP multilateral platforms & Europe \\
\hline & Restrictive measures due to Human Rights violations & Nuclear safety \\
\hline \multirow[t]{17}{*}{ Georgia } & 1999_Partnership and Cooperation Agreement & Democracy and \\
\hline & 2003-EU Special Representative for the South & Human Rights \\
\hline & Caucasus & DCFTA \\
\hline & 2004-EUJUST THEMIS, Rule of law ESDP & implementation \\
\hline & Mission & Conflicts in \\
\hline & 2006-ENP Action Plan & Abkhazia and South \\
\hline & 2008-EU Monitoring Mission (EUMM), civilian & Ossetia \\
\hline & CSDP monitoring mission & Relations with \\
\hline & 2008-EU Special Representative (EUSR) for the & Russia \\
\hline & South Caucasus and the Crisis in Georgia & Energy \\
\hline & 2008-EUSR co-chairs Geneva International & Security cooperation \\
\hline & $\begin{array}{l}\text { Discussions on the Abkhaz and South Ossetian } \\
\text { conflicts }\end{array}$ & \\
\hline & 2011 -Visa facilitation and readmission agreements & \\
\hline & 2016-Association Agreement, including Deep and & \\
\hline & Comprehensive Free Trade Area & \\
\hline & 2017-EU adopts visa liberalisation policy for & \\
\hline & Georgian nationals & \\
\hline
\end{tabular}


Table 2.2 (continued)

\begin{tabular}{|c|c|c|}
\hline Country & Major agreements & Major topics \\
\hline Moldova & $\begin{array}{l}\text { 1994-Partnership and Cooperation Agreement } \\
2005 \text {-ENP Action Plan } \\
\text { 2005-EU Border Assistance Mission to Moldova and } \\
\text { Ukraine (EUBAM), ENP funded mission with } \\
\text { technical and advisory functions } \\
2005 \text {-EU joins the } 5+2 \text { mediation format on the } \\
\text { Transnistrian conflict } \\
2014 \text {-EU adopts visa liberalisation policy for } \\
\text { Moldovan nationals } \\
\text { 2016-Association Agreement, including Deep and } \\
\text { Comprehensive Free Trade Area }\end{array}$ & $\begin{array}{l}\text { Democracy and } \\
\text { Human Rights } \\
\text { Economic } \\
\text { development and } \\
\text { trade relations } \\
\text { Justice and home } \\
\text { affairs } \\
\text { Conflict settlement }\end{array}$ \\
\hline Ukraine & $\begin{array}{l}\text { 1994-Partnership and Cooperation Agreement } \\
\text { 2005-ENP Action Plan } \\
\text { 2005-EU Border Assistance Mission to Moldova and } \\
\text { Ukraine (EUBAM), ENP funded mission with } \\
\text { technical and advisory functions } \\
\text { 2008-Visa facilitation and readmission agreements } \\
2014 \text {-European Union Advisory Mission to Ukraine, } \\
\text { assisting reforms of the security sector } \\
\text { Since } 2014 \text { - Restrictive measures related to the } \\
\text { ongoing armed conflict in Eastern Ukraine and the } \\
\text { annexation of Crimea } \\
2017 \text {-EU adopts visa liberalisation policy for } \\
\text { Ukrainian nationals } \\
\text { 2017-Association Agreement, including Deep and } \\
\text { Comprehensive Free Trade Area (provisional } \\
\text { application of the AA since } 2014 \text { and of the DCTFA } \\
\text { since 2016) }\end{array}$ & $\begin{array}{l}\text { Democratic reforms } \\
\text { Economic } \\
\text { development and } \\
\text { trade relations } \\
\text { Conflict } \\
\text { management } \\
\text { Reform of state } \\
\text { administration }\end{array}$ \\
\hline
\end{tabular}

enlargement perspectives for the time being (the new Obama Administration had clearly abandoned that goal and was now embarking on a policy of 'reset' with Russia), it was up to the EU to respond positively to the pro-western ambitions of some of these countries. This was done by combining structural approaches to security, namely the negotiation of new Association Agreements, including Deep and Comprehensive Free Trade Agreements, as well as the use of CSDP missions, as was the case of the EU Monitoring Mission of Georgia, tasked with monitoring the cease-fire agreement between Georgia and Russia. ${ }^{24}$ Although this is a

${ }^{24}$ Maria Raquel Freire and Licínia Simão, 'The EU's Security Actorness: The case of EUMM in Georgia', European Security 22: 4 (2013), pp. 464-477. 
civilian mission, it reflects the EU's political will to contribute to peace and security in contexts of armed conflict, as well as the acknowledgement of the geopolitical significance of doing so.

Following the war in Georgia, the EU clearly became a more significant partner to the region, as a result both of its Eastern Partnership initiative and of its willingness to become more engaged in regional conflict management. This dual approach reinforced both the structural dimension of security provision, deepening integration in economic and political terms, and it contributed to address hard security challenges, with the deployment of a new CSDP mission. This was clearly in line with the EU's desire of developing a comprehensive and integrated approach to regional security, which had been absent from the initial stages of the ENP, due to both the lack of internal capabilities and the lack of external incentives, including a stronger US military presence in Eurasian affairs. The new post-Lisbon context and the Obama-led reset policy with Russia and his 'pivot to Asia' provided the EU with the conditions and incentives for a greater role.

This new presence reflected stronger geopolitical incentives driving EU policy. The official EU discourse became heavily influenced by perceptions of a new Russian threat, emerging since the 2006 and 2009 energy crises and most visibly with the Georgian war of $2008 .{ }^{25}$ As argued by Simão and Dias, 'Moscow's strategies in the region and its discourses about European regional policies are increasingly seen by EU countries as a threat and constraint to the security of bordering countries $[\ldots] .{ }^{26}$ Illustrating this trend, the 'Review of EU-Russia relations' published by the European Commission after the Georgian-Russian War demonstrates EU perceptions of power relations in the region:

The EU can approach its relationship with Russia with a certain confidence. Economically, Russia needs the EU. The EU is an important market for its exports of raw materials, notably energy ... The recent financial crisis has underlined how acutely Russia needs to modernize and diversify its economy. The EU is a natural partner for this process, and the main source of its foreign investments. ${ }^{27}$

${ }^{25}$ RFE/RL. The View from Europe. Radio Free Europe/Radio Liberty, 27 August 2008. http://www.rferl.org/content/The_View_From_Europe/1194356.

${ }^{26}$ Licínia Simão and Vanda Amaro Dias, 'The securitization of the EU's Eastern neighbourhood: What role for Russia?', in Remi Piet and Licínia Simão (eds.), Security in Shared Neighbourhoods - Foreign Policy of Russia Turkey, and the EU. London: Palgrave Macmillan, 2016 , p. 114.

${ }^{27}$ European Commission. Review of EU-Russia Relations. Communication from the Commission to the Council, COM (2008) 740 final, Brussels, 5 November 2008, p. 2. 
The document presents a blatant condemnation of the 'disproportionate Russian reaction' in Georgia and recognises that a contested field of influence thereafter exists in the shared neighbourhood. Whereas the EU builds on the self-assessed success of the EUMM in Georgia to claim more political will and operational capability to perform a leading role in conflict resolution and the transformation of the political and economic environment at its borders, ${ }^{28}$ Russia claims special interests in the region. The driving tension between competing geopolitical projects for the postSoviet space has been an element of destabilisation of the EU's neighbourhood policy, as have the political developments in its southern periphery, bringing overarching changes to the policy, as analysed below.

\section{Building Security with the Neighbouring Societies in a Post-Arab Spring Context}

The nature of the EU's deeper engagement with its eastern neighbourhood, in the context of the EaP, was profoundly influenced by the events developing in North Africa and the Middle East as of 2010. The popular uprisings known as the Arab Spring brought an added layer of pressure onto EU policies of regional stabilisation, pushing for a new inflection in the ENP. The most significant shift in this regard was the recognition, by EU institutions and member states, that the Union's government-centred approach to promoting regional reforms had been unable to translate into improved economic and social conditions in its neighbourhood and, in some cases, had even reinforced the legitimacy of authoritarian and repressive regimes. The ENP review document of 2011 states that '[a] new approach is needed to strengthen the partnership between the EU and the countries and societies of the neighbourhood: to build and consolidate healthy democracies, pursue sustainable economic growth and manage cross-border links'. ${ }^{29}$

In line with this view, a clear normative stance is reintroduced in EU discourse and, to some extent, also in its practice. A focus on democratic

${ }^{28}$ Ibid.

${ }^{29}$ European Commission and High Representative of the European Union for Foreign Affairs and Security Policy. A new response to a changing Neighbourbood. Joint communication to the European Parliament, the Council, the European Economic and Social Committee and the Committee of the Regions. $\operatorname{COM}(2011) 303$ final, Brussels, 25.5.2011, p. 1 (emphasis added). 
and human rights-related conditionality is reinforced in EU official documents. The above-mentioned communication states that '[i]ncreased EU support to its neighbours is conditional. It will depend on progress in building and consolidating democracy and respect for the rule of law'. It further reads that 'The EU will uphold its policy of curtailing relations with governments engaged in violations of human rights and democracy standards, including by making use of targeted sanctions and other policy measures' ${ }^{30}$ 'Deep democracy' is presented as a central objective of the ENP, and a hint of self-criticism is discernible in the indication that the ENP should 'support inclusive economic development-so that EU neighbours can trade, invest and grow in a sustainable way, reducing social and regional inequalities, creating jobs for their workers and higher standards of living for their people'. ${ }^{31}$

These normative goals of the EU, although largely driven by the events in its southern periphery, also provided the impetus for change in the EaP. The initiative clearly developed in a more horizontal approach, with the EU underlining 'partnership' and joint ownership of the process as fundamental elements, ${ }^{32}$ and with a more transversal reading of societies also being incorporated into EU initiatives. Illustrating this, the EaP developed such initiatives as a Civil Society Forum, programmes to support Small and Medium Size Enterprises, a Business Forum and a Parliamentary dimension, among others, aimed at legitimising other non-governmental stakeholders in the reform processes. The political decision to open the EU internal market to the eastern neighbours, through the negotiation of DCFTAs, reinforces this normative view, since the EU has been very reluctant to allow non-EU members to operate in the EU internal market, but it naturally reinforces one of the EU's most tangible geopolitical tools for regional influence, which is the Union's economic power. Moreover, it does so in a very structured and top-down manner, since in this field partner countries are required to adopt the EU acquis communautaire, reinforcing regional power diffusion dynamics.

${ }^{30}$ Ibid., p. 3.

${ }^{31}$ Ibid., p. 3.

${ }^{32}$ Elena Korosteleva, 'The Eastern Partnership Initiative: A New Opportunity for Neighbours?', Journal of Communist Studies and Transition Politics 27: 1 (2011), p. 11. 


\section{Adopting a Global Strategy in a Post-Crimea CONTEXT}

The escalation of violence in Ukraine in February 2014, following the socalled Maidan protests contesting former president Yanukovych's refusal to sign the Association Agreement with the EU at the EaP Vilnius Summit in November 2013, and the overall corrupt actuation of the political elites in the country, brought once more war to Europe. The organisation of a referendum in Crimea, which took place on 16 March 2014, and the subsequent annexation of the peninsula by Russia ${ }^{33}$ violated international and Ukrainian legislation on states' sovereignty questioning the long-established European borders' regime. ${ }^{34}$ President Putin commenting on the referendum results, overwhelmingly in favour of the 'reunification with Russia', ${ }^{35}$ stated that the signature of the reunification treaty two days after the referendum took place showed a simple disposition, "we did what we had to do'. ${ }^{36}$ At the time, the Russian president underlined that the process was 'in full compliance with democratic procedures and international norms' ${ }^{37}$

The new insecurity context focused largely on territorial issues and a militarised approach from Russia, to which the EU response was late and mainly focused on the adoption of sanctions targeting Russia. The Minsk agreements' provisions are hard to implement, ${ }^{38}$ not to mention that they ignore the status of Crimea and are blocking progress in changing the current status quo of difficult relations between the EU and Russia. Despite the EU not having been directly involved in the negotiations, the linking of sanctions to implementation of the decisions reached has been central to the EU's approach. The latter focus essentially in the provision of sup-

\footnotetext{
${ }^{33}$ Vladimir Putin, 'Address by President of the Russian Federation to State Duma deputies, Federation Council members, heads of Russian regions and civil society representatives in the Kremlin', Moscow. 18 March 2014.

${ }^{34}$ Maria Raquel Freire, 'Ukraine and the Restructuring of East-West Relations', in Roger E. Kanet (ed.), The Russian Challenge to the European Security Environment. London: Palgrave Macmillan, 2017.

${ }^{35}$ The Guardian, 'Crimea votes to secede from Ukraine in "illegal” poll', 16 March 2014.

${ }^{36}$ Vladimir Putin, "We did What We had to DO" Putin OPENS Up On Crimea Reunification PLAN', Interview with RT, 10 March 2015, available at: https://www.youtube.com/watch?v=a_hN24Ceing.

${ }^{37}$ Vladimir Putin, 'Address by President of the Russian Federation to State Duma deputies, Federation Council members, heads of Russian regions and civil society representatives in the Kremlin', Moscow, 18 March 2014.

${ }^{38}$ The Telegraph, 'Minsk agreement on Ukraine crisis: text in full', 5 October 2017.
} 
port and good offices, though the measures to follow up on the Minsk agreements need to be put forward and monitored by the actors directly involved. In a difficult setting, where the transformative potential of the EU in the neighbourhood revealed clear limits, the EU adopted the 'Global Strategy for the European Union's Foreign and Security Policy'. The new document entitled 'Shared Vision, Common Action: A Stronger Europe' seeks to become the backbone for the EU's affirmation as a global actor, as well as an actor with 'global' outreach tools, in the post-Lisbon institutional context. Towards this end, the Global Strategy acknowledges the diverse nature of threats, the comprehensive response needed to address them, as well as the EU's role as a security promoter during times of instability. In the wording of the document,

We live in times of existential crisis, within and beyond the European Union. Our Union is under threat. Our European project, which has brought unprecedented peace, prosperity and democracy, is being questioned. To the east, the European security order has been violated, while terrorism and violence plague North Africa and the Middle East, as well as Europe itself. Economic growth is yet to outpace demography in parts of Africa, security tensions in Asia are mounting, while climate change causes further disruption. Yet these are also times of extraordinary opportunity. Global growth, mobility, and technological progress-alongside our deepening partnerships-enable us to thrive, and allow ever more people to escape poverty and live longer and freer lives. ${ }^{39}$

The development of the Global Strategy coincides with important shifts ongoing both within EU strategic thinking and institutional capacity in the post-Lisbon context, as well as in the international context. On the internal EU level, the United Kingdom's decision to trigger Article 50 of the Lisbon Treaty, leading to negotiations for leaving the EU, has propelled the Union to think about the impacts of losing its most significant military power and a strong geopolitical player. The opportunities for EU military capabilities development, which the establishment of the European Defence Agency with the Lisbon Treaty allowed, have been seized by the EU HR Federica Mogherini and endorsed by the European Council in

\footnotetext{
${ }^{39}$ European Union Global Strategy, Shared Vision, Common Action: A Stronger Europe. A Global Strategy for the European Union's Foreign and Security Policy, Brussels, June 2016, p. 8 .
} 
2016, through the adoption of the so-called winter-package.$^{40}$ The political and financial means to develop an internal armaments market of the $\mathrm{EU}$ is the ultimate goal, perceived as an important step to make the EU a relevant regional and global military power. This is a significant departure from the historical views of EU actorness, based on civilian means. Whether the EU will prove itself both a normative and a military actor is one of the most significant aspects of this change.

This shift also needs to be framed in the context of the post-2008 financial crisis and the Trump Administration policies regarding European security, particularly evidenced in the additional pressure on NATO's burden-sharing, with implications for European states' budgetary policies. The legitimacy of the western economic model has been severely affected by the financial crisis and the trends towards xenophobia, racism and the return of nationalist and extremist ideologies to western political institutions has also created uncertainty regarding the legitimacy of liberal democracy. The difficulties in managing the refugees and migrants' flows to the EU are here also a good example of the hardship in finding a coherent line of reasoning among the EU member states on how to deal with these new challenges to the old normative core principles of the Union. The instrumentalisation of political discourse for the sake of nationalistpopulist goals has evidenced the linkages made between security, economics, terrorism and migration. The consequences of this distorted political rhetoric are visible in the lack of agreement between member states on how to address some of these fundamental changes, and particularly regarding the refugee/migrant issue. Using this context, emerging powers, namely Russia, have contested the normative stance of the West and of the EU's regional policies, in particular.

The EU's security actorness is still defined by the three main elements mentioned, namely presence, opportunity and capacity, but the way these are framed changed. In fact, the 'transformational diplomacy'4l that was very much present in the EU's structural security approach has been superseded by a stability-building approach translated into the promotion

\footnotetext{
${ }^{40}$ European Council European Council conclusions, doc.34/16, Brussels, 15 December 2016; Steven Blackmans, The 2016 "Winter Package" on European Security and Defence: Constitutional, Legal and Institutional Implications. Report for the European Parliament Directorate General for Internal Policies, Policy Department C: Citizens' Rights and Constitutional Affairs. PE 571.405. Brussels. 16 December.

${ }^{41}$ Roland Dannreuther, 'Developing the Alternative to Enlargement: The European Neighbourhood Policy', European Foreign Affairs Review No. 2 (2006), pp. 183-201.
} 
of the so-called 'state and societal resilience'. ${ }^{42}$ This change denotes the recognition that the EU neighbours have agency, implying a less-intrusive EU approach. But this also means that the EU needs to rethink its strategy towards the neighbourhood in order that its engagement is differentiated and more effective. The new framing document combines in a very clear way the structural and hard security approaches, along with the combination of the normative and geopolitical dimensions of the EU as a security actor. This framing opens new opportunities for relations between the EU and its neighbours seeking to recover the attraction effect the EU might have as a security project.

\section{Conclusion}

The evolution of the EU's security actorness has had a primordial test in its vicinity. Both in terms of the challenges to political and economic stability and in terms of conflict management, the neighbouring regions to the East and South of the EU have been perceived as presenting fundamental challenges. The ENP has been an important tool putting forward a comprehensive and integrated approach to EU engagement with these regions, particularly to the East. Seeking to replace enlargement as a policy for regional stabilisation and development, the ENP and particularly the $\mathrm{EaP}$ have benefitted from the important institutional developments brought about by the Lisbon Treaty, reinforcing EU coherence and operational capabilities. Moreover, the global context has also reinforced the view in Brussels and in other European capitals that the EU is needed as a security provider, both globally and regionally.

This EU response has had, nevertheless, a poor track record, if one is to measure success by the replication of the EU model in its vicinity. The EU's neighbourhood has been immersed into political and military conflict; it has performed poorly in economic terms and remains a security challenge, as evidenced by the EU's migratory policies put in place to stop the flow of migrants across its southern and south-eastern borders. The combination of structural security tools, taken from accession processes, and hard security tools, developed since the early 2000s in many civilian and military missions worldwide, has placed the EU as a more

${ }^{42}$ European Union Global Strategy, 'Shared Vision, Common Action: A Stronger Europe. A Global Strategy for the European Union's Foreign and Security Policy', Brussels, June 2016 , p. 9. 
coherent security actor. This has also reinforced its desire to take a stronger role in regional security affairs, expanding its regional influence. We can therefore say that the EU has advanced its geopolitical interest through the use of its structural policies, although whether they represent a normative approach is harder to tell. The stated goals are normative, but the results and means are sometimes replicating hierarchical relations and centre-periphery dynamics.

Acknowledgements The authors acknowledge funding for research from the Marie Skłodowska-Curie Innovative Training Networks (ITN-ETN) of the European Union's Horizon 2020 research and innovation programme, under grant agreement 'CASPIAN-Around the Caspian: A Doctoral Training for Future Experts in Development and Cooperation with Focus on the Caspian Region' (642709-CASPIAN-H2020-MSCA-ITN-2014).

\section{REFERENCES}

Adler, Emmanuel and Michael Barnett (eds), Security Communities (Cambridge: Cambridge University Press, 1998), pp. 69-118.

Averre, Derek, 'Competing rationalities: Russia, the EU and the "Shared Neighbourhood", Europe-Asia Studies 61:10 (2009), pp. 1689-713.

Blackman, Steven, "The 2016 "Winter Package" on European Security and Defence: Constitutional, Legal and Institutional Implications', Report for the European Parliament Directorate General for Internal Policies, Policy Department C: Citizens' Rights and Constitutional Affairs, Brussels, 16 December 2016, available at: PE 571.405.

Bretherton, Charlotte and John Vogler, The European Union as a Global Actor (London: Routledge, 2006).

Burgess, J. Peter, 'There is No European Security, Only European Securities', Cooperation and Conflict 44:3 (2009).

Cierco Gomes, Teresa (ed.), The European Union and Its Immediate Neighbourhood (Aldershot: Ashgate, 2013).

Communication from the Commission, 'Wider Europe Neighbourhood. A New Framework for Relations with our Eastern and Southern Neighbours', Brussels, March 2003, available at: COM (2003a) 104.

Communication from the Commission, 'Paving the Way for a New Neighbourhood Instrument', Brussels, July 2003, available at: COM (2003b) 393.

Copenhagen European Council, 'Conclusions of the Presidency', 21-22 June, 1993, available at: SN 180/1/93 REV 1.

Council of the European Union, 'Joint Declaration of the Prague Eastern Partnership Summit', Brussels/Prague, 7 May, 2009, available at: 8435/09 (Presse 78). 
Dannreuther, Roland, 'Developing the Alternative to Enlargement: The European Neighbourhood Policy', European Foreign Affairs Review 11:2 (2006), pp. 183-201.

Deutsch, Karl et al., Political Community and the North Atlantic Area (Princeton, NJ: Princeton University Press, 1957).

European Commission, 'Review of EU-Russia Relations', Communication from the Commission to the Council, Brussels, 5 November, 2008, available at: COM (2008) 740 final.

European Commission and EEAS, The EU's Comprehensive Approach to External Conflict and Crisis (Brussels: EU, 2013).

European Commission and High Representative of the European Union for Foreign Affairs and Security Policy, 'A new response to a changing Neighbourhood', Joint communication to the European Parliament, the Council, the European Economic and Social Committee and the Committee of the Regions, Brussels, 25 May, 2011, available at: $\operatorname{COM(2011)~} 303$ final.

European Council, 'European Council conclusions', Brussels, 15 December, 2016, available at: doc.34/16.

European Security Strategy, 'A Secure Europe in a Better World', Brussels, 12 December, 2003.

European Union Global Strategy, 'Shared Vision, Common Action: A Stronger Europe. A Global Strategy for the European Union's Foreign and Security Policy', Brussels, June 2016.

Higashino, Atsuko, 'For the Sake of "Peace and Security"? The Role of Security in the European Union Enlargement Eastwards', Cooperation and Conflict 39:4 (2004), pp. 347-68.

Kanet, Roger E. (ed.), The Russian Challenge to the European Security Environment (London: Palgrave Macmillan, 2017).

Kaunert, Christian, 'Europol and EU Counterterrorism: International Security Actorness in the External Dimension', Studies in Conflict \& Terrorism 33:7 (2010), pp. 652-71.

Korosteleva, Elena, 'The Eastern Partnership Initiative: A New Opportunity for Neighbours?', Journal of Communist Studies and Transition Politics 27:1 (2011), pp. 1-21.

Lisbon Treaty, 'Treaty of Lisbon, Amending the Treaty on the European Union and the Treaty establishing the European community', Official Journal of the European Union, 17 December, 2007 available at: 2007/C 306/01.

Marsh, Steve and Wyn Rees, The European Union in the Security of Europe: From Cold War to Terror War (Oxford: Routledge, 2012).

Merlingen, Michael and Rasa Ostrauskaite (eds), European Security and Defence Policy: An Implementation Perspective (Oxford: Routledge, 2008).

Piet, Remi and Licínia Simão (eds), Security in Shared Neighbourhoods: Foreign Policy of Russia Turkey, and the EU (London: Palgrave Macmillan, 2016). 
Putin, Vladimir, "We did What We had to DO" Putin OPENS Up On Crimea Reunification PLAN', Interview with RT, 10 March, 2015, available at: https://www.youtube.com/watch?v=a_hN24Ceing.

Putin, Vladimir, 'Address by President of the Russian Federation to State Duma deputies, Federation Council members, heads of Russian regions and civil society representatives in the Kremlin', Moscow, 18 March, 2014.

Raquel Freire, Maria, 'Challenges and opportunities at the EU's vicinity: assessing policies and practices', in Teresa Cierco Gomes (ed.), The European Union and Its Immediate Neighbourhood (Aldershot: Ashgate, 2013).

Raquel Freire, Maria, 'Ukraine and the Restructuring of East-West Relations', in Roger E. Kanet (ed.), The Russian Challenge to the European Security Environment (London: Palgrave Macmillan, 2017).

Raquel Freire, Maria, and Lícinia Simão, 'The EU's security actorness: the case of EUMM in Georgia', European Security 22:4 (2013), pp. 464-477.

RFE/RL, 'The View from Europe', Radio Free Europe/Radio Liberty, 27 August, 2008, available at: http://www.rferl.org/content/The_View_From_Europe/ 1194356.

Simão, Licínia and Vanda Amaro Dias, 'The securitization of the EU's Eastern neighbourhood: What role for Russia?', in Remi Piet and Licínia Simão (eds), Security in Shared Neighbourhoods: Foreign Policy of Russia Turkey, and the EU (London: Palgrave Macmillan, 2016).

Simão, Licínia, The EU's Neighbourhood Policy towards the South Caucasus: Expanding the European Security Community (London: Palgrave Macmillan, 2018).

Stamnes, Eli, 'The European Union and Peacebuilding', Norwegian Institute of International Affairs, Policy Brief Series, 3 March 2016.

Wrver, Ole, 'Insecurity, security, and asecurity in the West European non-war community', in Emmanuel Adler and Michael Barnett (eds), Security Communities (Cambridge: Cambridge University Press, 1998), pp. 69-118. 